\title{
PENGARUH PENGGUNAAN PUPUK ORGANIK MIKROORGANISME LOKAL MEDIA NASI, BATANG PISANG, DAN IKAN TONGKOL TERHADAP PERTUMBUHAN TANAMAN SAWI (Brassica juncea)
}

\author{
Ikra Mursalim \\ Jurusan Pendidikan Biologi Fakultas Tarbiyah dan Ilmu Keguruan, UIN Alauddin \\ Makassar, Kampus II Jl. H. M. Yasin Limpo No 36. Samata-Gowa \\ Sulawesi Selatan 92118, Telepon: (0411) 424835 \\ Email: ikramursalim@gmail.com \\ Muh. Khalifah Mustami \\ Jurusan Pendidikan Biologi Fakultas Tarbiyah dan Ilmu Keguruan, UIN Alauddin \\ Makassar, Kampus II Jl. H. M. Yasin Limpo No 36. Samata-Gowa, \\ Sulawesi Selatan 92118, Telepon: (0411) 424835 \\ Email:muhkhalifahmustami@gmail.com

\begin{abstract}
Ahmad Ali
Jurusan Pendidikan Biologi Fakultas Tarbiyah dan Ilmu Keguruan, UIN Alauddin Makassar, Kampus II J1. H. M. Yasin Limpo No 36. Samata-Gowa, Sulawesi Selatan 92118, Telepon: (0411) 424835, Email: ahmad.ali@uin-alauddin.ac.id
\end{abstract}

\begin{abstract}
Abstrak
Penelitian ini dilakukan untuk mengetahui pengaruh pupuk organik mikroorganisme lokal media nasi, batang pisang, dan ikan tongkol terhadap pertumbuhan tanaman sawi (Brassica juncea). Penelitian ini merupakan penelitian eksperimen dengan mengunakan rancangan acak lengkap (RAL) 4 perlakuan dan 5 ulangan sehingga diperoleh 20 satuan percobaan. Perlakuan A (perlakuan kontrol), Perlakuan B (10\%), Perlakuan C (15\%), dan Perlakuan D (20\%). Variabel yang diukur adalah pertumbuhan tanaman Sawi (Brassica juncea) yang meliputi berat basah tanaman, jumlah daun dan tinggi tanaman. Data hasil penelitian dianalisis menggunakan analisis of varians (ANOVA) dengan uji lanjut menggunakan uji Duncan. Hasil penelitian menunjukkan bahwa pupuk organik mikroorganisme lokal media nasi, batang pisang, dan ikan tongkol memberikan pengaruh nyata terhadap pertumbuhan tanaman Sawi (Brassia juncea) yang dalam hal ini pada berat basah tanaman, jumlah daun, dan tinggi tanaman. Selain Itu, peningkatan dosis pupuk tidak memberikan hasil yang tinggi terhadap pertumbuhan tanaman Sawi, hal tersebut dapat diketahui dari konsentrasi/dosis pupuk yang memberikan pengaruh paling tinggi terhadap pertumbuhan (Berat basah, jumlah daun, dan
\end{abstract}


tinggi) tanaman Sawi adalah konsentrasi/dosis 10\% (Perlakuan B) yang merupakan penggunaan dosis pupuk paling rendah.

Kata kunci: Pupuk organik mikroorganisme lokal, pertumbuhan Tanaman Sawi (Brassia juncea)

\begin{abstract}
This research was conducted to find the influence of local microorganism fertilizer by cooked rice, banana tree and tuna fish for the growth of the mustard greens plants (Brassica juncea). This research was an experimental research using Completely Randomized Design (CRD) with has 4 randomizations and 5 replications which delivered to 20 experiments. There were A treatment as a control, treatment $B$ with $10 \%$ concentration of fertilizer, treatment $C$ with $15 \%$ concentration of fertilizer, treatment B with $20 \%$ concentration of fertilizer (20\%). The variable growth that was measured of mustard greens (Brassica juncea) namely wet weight of the plant, number of leaves, and the high of the plant. Data of research was analyzed by using analysis of variance (ANOVA) and continued with Duncan test. The result showed that local microorganism fertilizer by cooked rice, banana tree and tuna fish gave impact for mustard green (Brassica juncea) growth, they were wet weight of the plant, number of leaves, and the high of the plant. Another fact was the increasing in fertilizer dosage did not affect the growth of mustard greens since it found the highest wet weight of the plant, number of leaves, and plant height only to treatment B with $10 \%$ concentration of fertilizer which was the lowest dosage.
\end{abstract}

Key words: Local Microorganism organic fertilizer, growth of mustard greens ( Brassica juncea)

\title{
PENDAHULUAN
}

Sayuran merupakan salah satu komoditas penting dalam mendukung ketahanan pangan nasional serta pemenuhan gizi masyarakat. Komoditas ini memiliki keragaman yang luas dan berperan sebagai sumber karbohidrat, protein nabati, vitamin, dan mineral yang bernilai ekonomi tinggi (Manure, 2014). Oleh karena itu, produksinya harus terus ditingkatkan.

Peningkatan produksi tanaman selain terkait dengan peningkatan luas areal tanam juga dalam hal peningkatan kesuburan tanah melalui pemupukan (Manure, 2014). Sebagian besar petani di negara berkembang seperti di Indonesia masih menggantungkan penggunaan bahan kimia dalam pengendalian penyakit tanaman serta pemupukan tanaman(Rinanto 2015). Hal tersebut menyebabkan ketergantungan petani pada masukan pupuk kimia yang terus menerus diberikan pada lahan pertaniannya 
sehingga berakibat menurunnya kesuburan tanah, kerusakan lingkungan, dan akibat lebih lanjut produktifitas tanah menurun(Manure, 2014). Selain itu, penggunaan pestisida dan pupuk kimia secara terus menerus dapat mencemari lingkungan juga menimbulkan efek yang merugikan bagi hama nontarget. Dampak lain dari penggunaan bahan kimia pertanian adalah mengurangi populasi mikroorganisme yang berperan dalam daur biogeokimia tanah, serta mengurangi ketersediaan unsur hara dalam jangka waktu yang lebih lama. Oleh karena itu, perlu pengembangan biokontrol dan pupuk berbasis mikrooganisme yang dapat menggantikan bahan kimia pertanian (Rinanto 2015)

Hal lain yang dapat dilakukan untuk meningkatkan produksi sayuran adalah menambah bahan organik yang diharapkan dapat memperbaiki sifat fisik, kimia dan biologi tanah, karena kemampuan bahan organik berfungsi sebagai pengikat butiran primer tanah menjadi butiran sekunder sehingga membentuk agregat yang mantap dan memberikan pengaruh baik terhadap tanaman. Keadaan ini akan berpengaruh pada kemampuan tanah menahan air, ketersediaan hara akan lebih baik, serta mikrobamikroba yang berperan aktif dalam tanah akan bertambah baik jenis maupun jumlahnya. Bahan organik memilki peran penting sebagai sumber karbon, dalam pengertian luas sebagai sumber pakan dan sumber energi untuk mendukung kehidupan dan perkembangbiakan berbagai jenis mikroba tanah (Manure, 2014).

Upaya yang dilakukan dalam usaha tani tanpa menggunakan bahan-bahan kimia yang akan merusak lingkungan adalah dengan penggunaan mikroorganisme lokal (MOL). Mol adalah mikroorganisme yang dimanfaatkan sebagai starter dalam pembuatan pupuk organik padat maupun pupuk cair. Adapun bahan utama Mol terdiri dari beberapa komponen, yaitu karbohidrat, glukosa dan sumber mikroorganisme (Selly Salma dan Joko Purnomo, 2015).

Selain itu, Mikroorganisme lokal (MOL) adalah cairan hasil fermentasi dari substrat atau media tertentu yang berada di sekitar kita (misalnya nasi, buah-buahan, telur, susu, keong, dan lain-lain). Mol dapat juga diartikan mikroorganisme yang berasal dari substrat/bahan tertentu dan diperbanyak dengan bahan alami yang mengandung karbohidrat (gula), protein, mineral, dan vitamin.

Salah satu jasad renik yang mulai dikembangkan untuk pupuk hayati ialah mikro organisme lokal (MOL), yang ternyata tidak hanya dapat mempercepat pengomposan, akan tetapi juga memperbaiki kualitas kompos. MOL adalah cairan yang mengandung mikroorganisme (bakteri) yang berguna untuk tanaman dan kesuburan tanah seperti Rhizobium sp, Azospirillum sp, Azotobacter sp, Pseudomonas sp, Bacillus sp dan bakteri pelarut phospat dan merupakan hasil produksi sendiri dari bahan-bahan alami disekeliling kita (lokal) (Rahayu and Tamtomo 2017)

MOL adalah cairan yang mengandung mikroorganisme (bakteri) yang berguna untuk tanaman dan kesuburan tanah seperti Rhizobium sp, Azospirillum sp, Azotobacter sp, OPseudomonas sp, Bacillus sp dan bakteri pelarut phospat dan merupakan hasil produksi sendiri dari bahan-bahan alami disekeliling kita (lokal). Larutan MOL 
berpotensi sebagai perombak bahan organik, sehingga MOL dapat digunakan baik sebagai decomposer (Suriawiria 2005)

Salah satu jenis tanaman sayuran yang mudah dibudidayakan adalah sawi (Brassica juncea L.). Teknik budidaya tanaman sawi tak berbeda jauh dengan budidaya sayuran pada umumnya. Budidaya konvensional di lahan meliputi proses pengolahan lahan, penyiapan benih, teknik penanaman, penyediaan pupuk dan pestisida, serta pemeliharaan tanaman(Lapanjang and Yusuf n.d.).

Usaha meningkatkan kuantitas dan kualitas tanaman sayuran dengan suatu sistim pertanian dengan melakukan budidaya tanaman dengan menambahkan penggunaan pupuk organik mikroorganisme lokal pada tanaman sayuran yang merupakan teknologi yang mudah, ramah lingkungan serta berkelanjutan dan menguntungkan. Bagi petani yang menuntut pemakaian pupuk yang murah dan praktis bisa diarahkan untuk menggunakan pupuk organik mikroorganisme lokal nasi, batang pisang, dan ikan tongkol yang merupakan pupuk organik yang dapat dibuat dalam beberapa hari dan siap pakai dalam waktu singkat, selain itu pembuatan pupuk organik mikroorganisme lokal nasi, batang pisang, dan ikan tongkol biayanya murah dan mudah cara pembuatannya sehingga sangat efektif dan efisien bagi para petani dalam meningkatkan kesuburan tanah dan tanaman.

Hasil produksi sawi adalah daunnya, oleh karena itu pupuk yang diberikan sebaiknya banyak mengandung unsur Nitrogen ( $N$ ), karena salah satu fungsi $\mathrm{N}$ adalah untuk memperbaiki bagian vegetative tanaman terutama untuk membentuk zat hijau daun tanaman, sehingga proses fisiologis akan berjalan dengan baik seperti fotosintesis dan respirasi (Surtinah, 2006). Nutrisi Ikan tongkol mengandung unsur nitrogen $(\mathrm{N})$ yang berfungsi sebagai penyubur daun sedangkan nutrisi batang pisang mengandung kalium dan serat yang berfungsi memperkuat akar tanaman pada tahap pertumbuhan (Suaib, 2015). Berdasarkan uraian tersebut, penelitian ini memadukan pupuk organik dari mikroorganisme lokal nasi dengan pupuk organik mikroorganisme lokal ikan tongkol dan batang pisang yang kemudian diberikan pada tanaman sawi (Brassica juncea), di mana produk tanaman sawi yang banyak digunakan adalah daunnya sehingga diharapkan pupuk ini memberikan pengaruh terhadap pertumbuhan tanaman sawi.

Penelitian ini dilakukan untuk mengetahui respon pertumbuhan tanaman sawi (Brassica juncea) terhadap peningkatan dosis pupuk organik mikroorganisme lokal media nasi, batang pisang, dan ikan tongkol. Selain itu, juga untuk mengetahui pengaruh nyata pupuk organik mikroorgnisme lokal media nasi, batang pisang, dan ikan tongkol terhadap pertumbuhan tanaman sawi (Brassica juncea) serta untuk mengetahui dosis pupuk organik mikroorganisme lokal media nasi, batang pisang, dan ikan tongkol yang paling baik digunakan. 


\section{METODOLOGI PENELITIAN}

\section{Alat dan Bahan}

Alat dan bahan yang digunakan dalam melakukan penelitian ini yaitu: sekop, ember ukuran 5 liter, papan, polybag $15 \times 20 \mathrm{~cm}$, mistar, spray (alat semprot), kertas (koran bekas), timbangan, dan gelas ukur. Adapun bahan yang digunakan yaitu: air, air cucian beras, air kelapa, gula merah, ikan tongkol, batang pisang, nasi, dan biji sawi.

\section{Pembuatan Pupuk Organik Mikroorganisme Lokal}

Pupuk organik MOL nasi dibuat melalui tahapan sebagai berikut: 1) Menyiapkan wadah berbentuk kotak dari bahan papan dengan ukuran panjang $20 \mathrm{~cm}$, lebar $15 \mathrm{~cm}$, dan tinggi $7 \mathrm{~cm}$. 2) Mengisi wadah tersebut dengan nasi hingga setengah bagian kemudian menutupnya dengan kertas Koran dan memberi sedikit celah agar udara dapat tetap masuk. 3) Menempatkan wadah tersebut pada daerah yang teduh dan lembab misalnya dibawah pohon pisang, atau di bawah pohon bambu dan memastikannya agar tidak dapat diganggu oleh hewan misalnya ayam dan tidak terkena air hujan selama 5 hari hingga seluruh bagian permukaan nasi ditumbuhi oleh jamur atau cendawan. 4) Setelah seluruh permukaan nasi ditumbuhi oleh jamur atau mikroorganisme lainnya selanjutnya nasi tersebut dimasukkan ke dalam ember berukuran 5 liter sebanyak $1 \mathrm{~kg}$, namun terlebih dahulu membuang bagian nasi yang terdapat cendawan berwarna hitam agar tidak menghambat pertumbuhan mikroorganisme yang dibutuhkan. 5) Menambahkan air kelapa dan air cucian beras ke dalam ember masing-masing $500 \mathrm{ml}$ dan gula merah sebanyak $1 \mathrm{~kg}$, selanjutnya menambahkan air hingga setengah bagian ember atau sebanyak $1500 \mathrm{ml}$. 6) Menutup ember dengan kertas koran dan menyimpannya selama 14 hari (Suaib, 2015)

Pupuk organic MOL batang pisang dibuat dengan tahapan sebagai berikut : 1) Menyiapkan wadah atau ember berukuran 5 liter. 2) Menyiapkan batang pisang sebanyak $1 \mathrm{~kg}$, selanjutnya memotong batang pisang hingga menjadi bagian-bagian yang kecil dan memasukkannya ke dalam ember. 3) Menambahkan air kelapa dan air cucian beras kedalam ember masing-masing $500 \mathrm{ml}$ dan gula merah sebanyak $1 \mathrm{~kg}$, selanjutnya menambahkan air hingga setengah bagian ember atau sebanyak 1500 ml. 4) Menutup ember dengan kertas koran dan menyimpannya selama 14 hari (Suaib, 2015)

Pupuk organic MOL ikan tongkol dibuat dengan tahapan sebagai berikut: 1) Menyiapkan wadah atau ember berukuran 5 liter. 2) Menyiapkan ikan tongkol sebanyak $1 \mathrm{~kg}$, selanjutnya motong seluruh bagian ikan tongkol hingga menjadi bagian-bagian yang kecil dan memasukkannya ke dalam ember. 3) Menambahkan air kelapa dan air cucian beras kedalam ember masing-masing $500 \mathrm{ml}$ dan gula merah sebanyak $1 \mathrm{~kg}$, selanjutnya menambahkan air hingga setengah bagian ember atau sebanyak 1500 ml. 4) Menutup ember dengan kertas koran dan menyimpannya selama 14 hari. 5) Setelah disimpan selama 14 hari, akan muncul aroma alkohol sebagai hasil fermentasi selanjutnya pupuk siap digunakan (Suaib, 2015). Pupuk Organik Mikroorganisme Lokal (MOL) yang telah difermentasi kemudian dicampurkan dengan perbandingan 1:1:1. 
Komposisi ini kemudian diberikan pada tanaman sawi (Brassica juncea) dengan konsentrasi yang berbeda.

\section{Pembenihan Tanaman Sawi}

Pembenihan dilakukan pada wadah yang berukuran panjang $30 \mathrm{~cm}$, lebar $20 \mathrm{~cm}$, dan tinggi $10 \mathrm{~cm}$. Media yang digunakan adalah tanah, lalu media dibasahi kemudian benih ditabur pada media. Penyiraman dilakukan menggunakan sprayer/alat semprot setiap hari. Setelah berumur 2 minggu sejak disemaikan atau bibit telah berdaun 3-4 helai, bibit tanaman sawi siap dipindahkan pada media yang telah disiapkan.

\section{Pembuatan Media Tanam dan Penanaman}

Media tanam yang digunakan adalah tanah yang disimpan pada polybag berukuran $15 \mathrm{~cm}$ x $20 \mathrm{~cm}$. Tanah yang digunakan terlebih dahulu dilakukan pengadukan agar unsur hara yang ada di dalam tanah dapat homogen sehingga tidak mempengaruhi hasil penelitian. Penanaman bibit sawi dilakukan dengan memindahkan bibit yang telah berumur 2 minggu atau telah berdaun 3-4 helai ke dalam media tanam yang telah disiapkan.

\section{Pemeliharaan}

Pemeliharaan dilakukan dengan memberikan larutan nutrisi, yaitu pupuk organik mikroorganisme lokal media nasi, batang pisang, dan ikan tongkol yang telah diencerkan sesuai perlakuan. Pemberian nutrisi dilakukan dengan penyiraman secara langsung pada hari ke-5, ke-10, ke-15, ke-20, dan ke-25 setelah tanam.

\section{Pengukuran}

Pengukuran tinggi dan jumlah daun tanaman sawi dilakukan setiap hari ke-7 pada minggu ke-1, 2, 3, dan 4 setelah tanam, sedangkan pengukuran berat basah tanaman sawi dilakukan pada saat panen, yaitu hari ke-30 pada minggu ke-4 setelah tanam.

\section{Pengumpulan Data}

Desain penelitian menggunakan model Rancangan Acak Lengkap (RAL) menggunakan table angka acak menurut Fred (Gaspersz, 1991) dengan empat perlakuan dan lima kali ulangan. Data hasil penelitian dianalisis dengan analisis varians (ANOVA) dan dilanjutkan dengan uji Uji Duncan.

Tabel 1. Perlakuan Media Tanaman dengan Pupuk Organik Mikroorganisme Lokal

(MOL)

\begin{tabular}{cccc}
\hline No & Kode & Perlakuan & Dosis/Konsentrasi \\
\hline 1 & A & Kontrol/Air & Air \\
2 & B & Pupuk Organik MOL & $100 \mathrm{ml} / \mathrm{L} \mathrm{Air} \mathrm{(10 \% )}$ \\
3 & C & Pupuk Organik MOL & $150 \mathrm{ml} / \mathrm{L} \mathrm{Air} \mathrm{(15 \% )}$ \\
4 & D & Pupuk Organik MOL & $200 \mathrm{ml} / \mathrm{L} \mathrm{Air}(20 \%)$ \\
\hline
\end{tabular}




\section{HASIL PENELITIAN DAN PEMBAHASAN}

Tanaman sawi (Brassica juncea) menunjukkan respon pertumbuhan setelah pemberian pupuk organik mikroorganisme (MOL) lokal nasi, batang pisang, dan ikan tongkol. Respon pertumbuhan dapat diukur melalu berat basah, tinggi, dan jumlah daun. Repon pertumbuhan dapat diamati pada gambar 1.

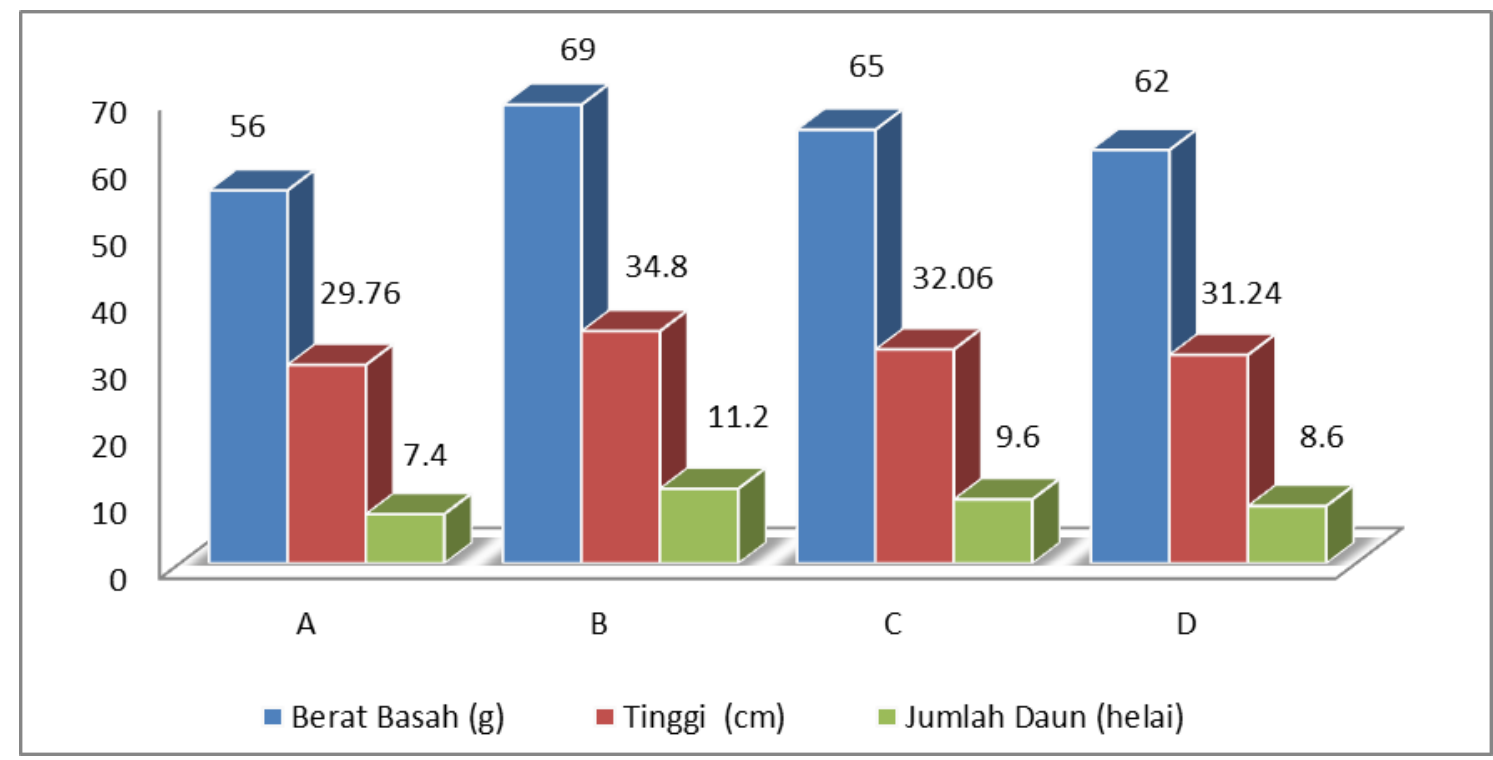

Gambar 1. Respon Pertumbuhan Tanaman Sawi (Brassica juncea)

\section{Berat Basah Tanaman Sawi (Brassica juncea)}

Berdasarkan data hasil penelitian pada gambar 1 diketahui bahwa rata-rata berat basah tanaman pada perlakuan tanpa MOL (Perlakuan A) sebesar 56 gram, dengan MOL 100 ml/L Air (Perlakuan B) sebesar, 69 gram, MOL 150 ml/L Air (Perlakuan C) sebesar 65 gram, sedangkan pemberian dengan MOL $200 \mathrm{ml} / \mathrm{L}$ Air (Perlakuan D) sebesar 62 gram.

Hasil analisis statistik dengan uji ANOVA diperoleh nilai $\mathrm{F}$ hitung $72.382>\mathrm{F}$ tabel 3.24 pada selang kepercayaan 95\% serta nilai sig. 0.000 yang menunjukkan adanya pengaruh nyata pemberian MOL media nasi, batang pisang, dan ikan tongkol terhadap pertumbuhan (berat basah) tanaman Sawi (Brassica juncea). Hasil uji lanjut dengan uji Duncan pada selang kepercayaan 95\% menujukkan perlakuan A menempati subset 1 (55.9020), perlakuan C dan D menempati subset yang sama yaitu subset 2 dengan hasil uji secara berurutan adalah 63.5520 dan 64.9860. sedangkan perlakuan B menempati subset 3 atau subset tertinggi dengan hasil uji 68.1340 yang menunjukkan bahwa perlakuan $\mathrm{B}$ memberikan pengaruh berbeda nyata terhadap berat basah tanaman sawi daripada perlakuan A, C, dan D. Sehingga hasil analisis menunjukkan bahwa perlakuan B (100 $\mathrm{ml} / \mathrm{L})$ adalah konsentrasi yang paling baik digunakan untuk pemupukan tanaman khususnya Sawi. 


\section{Jumlah Daun Tanaman Sawi (Brassica juncea)}

Berdasarkan gambar 1 diketahui bahwa rata-rata jumlah daun tanaman pada perlakuan tanpa MOL (Perlakuan A) sebesar 7,4 helai, dengan MOL 100 ml/L Air (Perlakuan B) sebesar 11,2 helai, MOL $150 \mathrm{ml} / \mathrm{L}$ Air (Perlakuan C) sebesar 9,6 helai, sedangkan pemberian dengan MOL 200 ml/L Air (Perlakuan D) sebesar 8,6 helai.

Hasil analisis statistik dengan uji ANOVA diperoleh nilai $\mathrm{F}$ hitung $32.333>\mathrm{F}$ tabel 3.24 pada selang kepercayaan 95\% serta nilai sig. 0.000 yang menunjukkan adanya pengaruh nyata pemberian MOL media nasi, batang pisang, dan ikan tongkol terhadap jumlah daun tanaman Sawi (Brassica juncea). Hasil uji lanjut Duncan diperoleh 4 subset dari 4 perlakuan. Perlakuan A menempati subset 1 dengan hasil uji 7.4000, perlakuan D menempati subset 2 dengan hasil uji 8.600, perlakuan $\mathrm{C}$ menempati subset 3 dengan hasil uji 9.6000, dan perlakuan B menempati subset 4 dengan hasil uji tertinggi 11.2000. Sehingga diketahui pada minggu ke-2 sampai minggu ke-4 ini perlakuan B selalu menempati subset tertinggi dan dapat diketahui bahwa perlakuan B adalah konsetrasi yang paling baik digunakan untuk pemupukan khususnya Sawi.

\section{Tinggi Tanaman Sawi (Brassica juncea)}

Berdasarkan data hasil penelitian pada gambar 1 diketahui bahwa rata-rata tinggi tanaman pada perlakuan tanpa MOL (Perlakuan A) sebesar 29,76 cm, dengan MOL 100 ml/L Air (Perlakuan B) sebesar 34,8 cm, MOL $150 \mathrm{ml} / \mathrm{L}$ Air (Perlakuan C) sebesar 32,06 cm, sedangkan pemberian dengan MOL $200 \mathrm{ml} / \mathrm{L}$ Air (Perlakuan D) sebesar $31,24 \mathrm{~cm}$.

Hasil analisis statistik dengan uji ANOVA diperoleh nilai $\mathrm{F}$ hitung 27.282 > F tabel 3.24 pada selang kepercayaan $95 \%$ serta nilai sig sebesar 0.001 yang menunjukkan adanya pengaruh nyata pemberian MOL media nasi, batang pisang, dan ikan tongkol terhadap jumlah daun tanaman Sawi (Brassica juncea). Hasil uji lanjut dengan uji Duncan diperoleh 3 subset. Perlakuan A dan D menempati subset 1 dengan nilai hasil uji masing-masing 29.7600 dan 31.2400, sehingga perlakuan A dan D tidak memberikan pengaruh yang berbeda nyata.

Subset 2 ditempati perlakuan D dan C (32.0600) menunjukkan bahwa antara perlakuan $\mathrm{D}$ dan $\mathrm{C}$ tidak memberikan pengaruh yang berbeda nyata tetapi antara perlakuan A dan C meberikan pengaruh yang berbeda nyata. Sedangkan subset 3 hanya terisi oleh perlakuan B dengan nilai hasil uji 34.8000 yang menunjukkan bahwa perlakuan B yang memberikan pengaruh yang paling berbeda nyata diantara ketiga perlakuan yang lain. 


\section{Pengaruh Pupuk Organik Mikroorganisme Lokal (MOL) Nasi, Batang Pisang, dan Ikan tongkol terhadap Pertumbuhan Tanaman Sawi (Brassica juncea)}

Hasil penelitian menunjukaan bahwa peningkatan konsentrasi pupuk organik mikroorganisme lokal nasi, batang pisang, dan ikan tongkol tidak menunjukkan peningkatan berat basah, jumlah daun, maupun tinggi tanaman. Konsentrasi pupuk MOL yang memberikan pengaruh nyata adalah pupuk dengan konsentrasi $100 \mathrm{ml} / \mathrm{L}$ air (10\%) atau perlakuan B. Sedangkan konsentrasi yang lebih tinggi (Perlakuan C dan D) tidak menunjukkan pengaruh yang lebih baik daripada perlauan B.

Dimana diketahui bahwa terdapat hubungan yang berbanding lurus antara berat basah tanama, jumlah daun, serta tinggi tanaman. Semakin banyak daun makan berat basah tanaman juga semakin besar begitupula dengan tinggi tanaman, makin tinggi tanaman berat basah tanaman juga semakin besar.

Pupuk Mikroorganisme lokal adalah cairan yang mengandung mikroorganisme (bakteri) yang berguna untuk tanaman dan kesuburan tanah (Julita, Gultom, and M Sc 2004) seperti rhizobium sp, azospirillum sp, azotobacter sp, pseudomonas sp, bacillus sp dan bakteri pelarut phospat dan merupakan hasil produksi sendiri dari bahan-bahan alami disekeliling kita (lokal) yang menyebabkan larutan pupuk mikroorganisme lokal berpotensi sebagai perombak bahan organik, sehingga mikroorganisme lokal dapat digunakan baik sebagai dekomposer(Suyanto and Irianti 2016).

Peningkatan dosis pupuk yang tidak disertai dengan peningkatan berat basah tanaman tersebut, diduga karena peningkatan dosis pupuk ini mengakibatkan banyaknya endapan hasil aktifitas mikroorganisme yang terkandung di dalam pupuk sehingga pertumbuhan tanaman Sawi menjadi terhambat. Pada penelitian yang lain dijelaskan bahwa adanya aktivitas mikroorganisme yang menghasilkan residu sehingga terjadi endapan dan menyebabkan terhambatnya aliran air dan unsur hara pada media tanam (Haryanto 2015)

Rendahnya berat basah tanaman Sawi sebagai akibat tingginya dosis pupuk yang digunakan juga diduga disebabkan oleh elektronik conduktifity (EC) yang sangat tinggi sehingga tanaman sulit menyerap unsur hara. Elektronik conduktifity (EC) adalah ukuran kemampuan suatu larutan untuk menghantarkan arus listrik. Arus listrik di dalam larutan dihantarkan oleh ion yang terkandung di dalamnya. Banyaknya ion dalam larutan dipengaruhi oleh padatan yang terlarut di dalamnya. Semakin besar jumlah padatan terlarut di dalam larutan maka kemungkinan jumlah ion dalam larutan juga akan semakin besar, sehingga nilai EC juga semakin besar (Irwan and Afdal 2016).

Pemberian pupuk organik ke dalam tanah dapat memperbaiki struktur tanah menjadikan tanah lebih gembur, sehingga sistem perakaran dapat berkembang lebih baik dan proses penyerapan unsur hara berjalan lebih optimal (Rahayu and Tamtomo 2017). Efek penggunaan nutrisi pada tanah tidak hanya diterima oleh tanaman, melainkan juga akan diterima oleh mikroba yang sebelumnya telah berada di dalam tanah sehingga saling mendukung dalam proses pertumbuhan tanaman (Geisseler and Scow 2014). Mikroba menguraikan senyawa organik sehingga dapat diserap kembali 
oleh tanaman sebagai nutrisi (Idham et al. 2016). Pengolahan lahan pertanian menggunakan pupuk organik secara tepat dipercaya dapat meningkatkan hasil pertanian secara signifikan khususnya sayuran (Li et al. 2017).

\section{KESIMPULAN}

Pupuk organik mikroorganisme lokal media nasi, batang pisang, dan ikan tongkol memberikan pengaruh nyata terhadap pertumbuhan tanaman Sawi (Brassica juncea) dengan dosis terbaik $100 \mathrm{ml} / \mathrm{L}$ Air (10\%).

\section{DAFTAR PUSTAKA}

Geisseler, Daniel, and Kate M Scow. (2014). "Long-Term Effects of Mineral Fertilizers on Soil microorganisms-A Review." Soil Biology and Biochemistry 75: 54-63.

Haryanto, Veranica In. (2015). "Pemanfaatan Limbah Cair Industri Tepung Aren Dan Mikroorganisme Lokal Sebagai Larutan Nutrisi Terhadap Pertumbuhan Dan Hasil Tanaman Baby Kailan (Brassica Oleracea) Dengan Sistem Hidroponik."

Idham, I, S Sudiarso, N Aini, and Y Nuraini. (2016). "Isolation and Identification on Microorganism Decomposers of Palu Local Cow Manure of Central Sulawesi, Indonesia." Journal of Degraded and Mining Lands Management 3(4): 625-29.

Irwan, Fadhilah, and Afdal Afdal. (2016). "Analisis Hubungan Konduktivitas Listrik Dengan Total Dissolved Solid (TDS) Dan Temperatur Pada Beberapa Jenis Air." Jurnal Fisika Unand 5(1): 85-93.

Julita, Sarmi, Hercule Gultom, and Mardaleni M Sc. (2004). "Pengaruh Pemberian Mikro Organisme Lokal (Mol) Nasi Dan Hormon Tanaman Unggul Terhadap Pertumbuhan Dan Produksi Tanaman Cabai (Capsicum Annum L.).” Dinamika Pertanian 28(3).

Lapanjang, Fitriani HamliIskandar M, and Ramal Yusuf. "Respon Pertumbuhan Tanaman Sawi (Brassica Juncea L.) Secara Hidroponik Terhadap Komposisi Media Tanam Dan Konsentrasi Pupuk Organik Cair.” AGROTEKBIS 3(3).

Li, Shuyan et al. (2017). "Effect of Different Organic Fertilizers Application on Growth and Environmental Risk of Nitrate under a Vegetable Field." Scientific reports 7(1): 17020.

Manure, Fertilizer Chicken. (2014). "Pertumbuhan Dan Produksi Tanaman Sawi (Brassica Juncea L) Dengan Pemberian Mikroorganisme Lokal (Mol) Dan Pupuk Kandang Ayam.” Jurnal Agrisistem 10(1): 1858-4330.

Rahayu, Sri, and F Tamtomo. (2017). "Efektivitas Mikro Organisme Lokal (Mol) Dalam Meningkatkan Kualitas Kompos, Produksi Dan Efisiensi Pemupukan N, P, K Pada Tanaman Ubi Jalar (Ipomoea Batatas L.)." Jurnal AGROSAINS 13(2).

Rinanto, Yudi. (2015). "Pemanfaatan Limbah Sisa Hasil Panen Petani Sayuran Di Boyolali Sebagai Bahan Baku Pembuatan Pupuk Cair Organik Menuju Pertanian 
Ramah Lingkungan." Prosiding KPSDA 1(1).

Suriawiria, Unus. (2005). "Mikrobiologi Dasar." Jakarta: Penerbit Papas Sinar Sinanti. Surtinah, Surtinah. (2006). "Peranan Plant Catalyst 2006 Dalam Meningkatkan Produksi Sawi (Brassica Juncea, L).” Jurnal Ilmiah Pertanian 3(1): 6-16.

Suyanto, Agus, and Agnes Tutik Purwani Irianti. (2016). "Efektivitas Trichoderma Sp Dan Mikro Organisme Lokal (Mol) Sebagai Dekomposer Dalam Meningkatkan Kualitas Pupuk Organik Alami Dari Beberapa Limbah Tanaman Pertanian.” Jurnal Agrosains 12(2). 